ISSN : 2550-0198

\title{
Pelatihan Keterampilan Menulis Fiksi Bagi Siswa SMKN 2 Marabahan
}

\author{
Sri Normuliati*, Istiqamah \\ Fakultas Keguruan dan Ilmu Pendidikan \\ Universitas Muhammadiyah Banjarmasin \\ email: srinormuliati@ymail.com
}

\begin{abstract}
Abstract. Dedication to this community to improve the ability to write fiction for SMKN 2 Marabahan students. To begin the process of writing fiction, you can start by writing a short story. Writing short stories can be done by first discussing the theme of the story to be made and discussing writing strategies. Short stories have relatively short stories with the shortest duration of about 500 words. The results of this community service show students have an interest in the field of writing fiction. In addition, students understand how to start writing fiction with themes raised and strategies for writing science fiction that are important to know.
\end{abstract}

Keyword: training, writing skills, fiction

\begin{abstract}
Abstrak
Abstrak. Pengabdian kepada masyarakat ini bertujuan untuk meningkatkan kemampuan menulis fiksi bagi siswa SMKN 2 Marabahan. Untuk memulai proses menulis fiksi, dapat dimulai dengan menulis cerita pendek. Menulis cerita pendek bisa dilakukan dengan terlebih dahulu memahami tema cerita yang akan dibuat dan memahami strategi menulis. Cerita pendek memiliki panjangnya cerita yang relatif pendek dengan durasi terpendek berkisar sekitar 500 an kata. Hasil dari kegiatan pengabdian kepada masyarakat ini menunjukkan bahwa para siswa memiliki ketertarikan dalam bidang menulis fiksi. Selain itu, para siswa mengetahui cara memulai menulis fiksi dengan memahami tema dan strategi menulis fiksi pengetahuan yang penting untuk diketahui.
\end{abstract}

Kata kunci: pelatihan, keterampilan menulis, fiksi

\section{PENDAHULUAN}

Menulis merupakan sebuah proses kreatif menuangkan gagasan dalam bentuk bahasa tulis dalam tujuan, misalnya memberitahu, meyakinkan, atau menghibur. Hasil dari proses kreatif ini biasa disebut dengan istilah karangan atau tulisan. Marwoto menjelaskan bahwa menulis adalah mengungkapkan ide atau atau gagasannya dalam bentuk karangan secara leluasa. Dalam hal ini, menulis itu membutuhkan skemata yang luas sehingga si penulis mampu menuangkan ide, gagasan, pendapatnya dengan mudah dan lancar. Skemata itu sendiri adalah pengetahuan dan pengalaman yang dimiliki[1].

Secara garis besar, ada tiga alasan utama orang menulis, yaitu alasan personal, profesional, dan sosial kemanusiaan. Alasan personal meliputi (1) pelepasan ide kreatif, seperti menulis karya puisi, cerpen, dan novel, (2) menulis buku harian, dan (3) membuat jadwal kegiatan pribadi. Alasan profesional, misalnya menulis surat dinas, membuat laporan, menulis berita, menulis pengumuman, membuat profil 
lembaga, dan merumuskan surat perjanjian. Sedangkan alasan sosial kemasyarakatan, misalnya berkomunikasi melalui surat, membuat dokumen perjanjian, mengirim sms, mms, dan lainnya.[2]

Sebagai salah satu aspek dari keterampilan berbahasa, menulis merupakan kegiatan yang kompleks. Kompleksitas menulis terletak pada tuntutan kemampuan untuk menata dan mengorganisasikan ide, pemikiran, pengetahuan, dan pengalaman secara runtut dan logis. Sayangnya, tidak banyak orang yang suka menulis. Di antara penyebabnya ialah karena orang merasa tidak berbakat serta tidak tahu bagaimana dan untuk apa menulis.[3]

Proses untuk menghasilkan sebuah tulisan, terutama menulis fiksi sering kali membuat banyak orang berhenti di tengah jalan. Mereka merasa kehilangan gairah dalam menulis, yang disebabkan oleh faktor teknis menulis maupun faktor internal penulis. Karena itu, penting untuk menumbuhkan tekad untuk menulis fiksi, mempunyai pengetahuan tentang cara membuat sebuah cerita fiksi serta bagaimana cara memulai menulis fiksi.

Nurhadi menyebut cerpen atau cerita pendek adalah karangan fiksi singkat, sederhana, dan berisi masalah tunggal, yang biasanya selesai dalam satu kali waktu membaca. Disebut cerita pendek, karena dilihat dari panjangnya cerita yang relatif pendek. Umumnya, sebuah cerpen diselesaikan oleh pembacanya dalam waktu lima belas menit sampai tiga puluh menit [2] Sementara, Nurgiyantoro menyebutkan bahwa ada cerpen yang pendek (short short story), bahkan mungkin pendek sekali, berkisar 500-an kata; ada cerpen yang panjangnya cukupan (midle short story), serta ada cerpen yang panjang (long short story) yang terdiri dari puluhan atau bahkan beberapa puluh ribu kata.[4]
Dalam menulis fiksi, seorang penulis mampu mengembangkan idenya dari segala sudut. Hal ini sejalan dengan ciriciri fiksi yang dibuat sebagus mungkin untuk menggugah emosi pembacanya, karya fiksi sangat dipengaruhi oleh subjektivitas pengarangnya, dan sebuah karya fiksi bisa memiliki berbagai makna[5].

Menulis fiksi bukan hanya sekedar menulis khayalan saja. Ada hal-hal penting yang harus diperhatikan, seperti dan bagaimana penokohan dihadirkan, bagaimana jalannya cerita dan bagaimana mendeskripsikan tempat dengan sangat apik. Contoh dalam menulis fiksi, unsur instrinsiknya juga jangan dilupakan keberadaannya. Untuk latihan menulis fiksi, dapat dilakukan dengan mengenali tema terlebih dahulu, kemudian menerapkan strategi-strategi dalam proses menulis fiksi.

Dengan pelatihan menulis fiksi ini, siswa diharapkan mampu menumbuhkan kecintaan dalam menulis karya fiksi, cerpen terutama. Selain itu, pelatihan ini juga memotivasi para siswa agar tidak merasa terbebani dengan keterampilan menulis fiksi.

\section{METODE PENGABDIAN}

Kegiatan pengabdian kepada masyarakat ini dilaksanakan pada tanggal 3 September 2019 di SMKN 2 Marabahan. Peserta terdiri dari 35 orang siswa dan juga satu orang guru mata pelajaran Bahasa Indonesia. Kegiatan ini dilaksanakan dengan metode ceramah, diskusi, tanya jawab dan praktik menulis fiksi secara langsung. Setelah praktik menulis fiksi, peserta mendapatkan masukan dari pemateri tentang cerita yang dihasilkan.

Tahapan kegiatan pelatihan menulis fiksi. 
Table 1. kegiatan pelatihan menulis

\begin{tabular}{|c|l|l|l|}
\hline No & \multicolumn{1}{|c|}{ Kegiatan } & Metode & \multicolumn{1}{c|}{$\begin{array}{c}\text { Keteranga } \\
\text { n }\end{array}$} \\
\hline 1. & $\begin{array}{l}\text { Pemaparan } \\
\text { materi } \\
\text { tentang } \\
\text { mengenali } \\
\text { tema dan } \\
\text { strategi } \\
\text { menulis } \\
\text { fiksi. }\end{array}$ & Ceramah & Pemateri \\
\hline 2. & $\begin{array}{l}\text { Tanya } \\
\text { jawab/diskus } \\
\text { i seputar } \\
\text { permasalaha } \\
\text { n dalam } \\
\text { mengenali } \\
\text { tema dan } \\
\text { strategi } \\
\text { menulis } \\
\text { fiksi. }\end{array}$ & $\begin{array}{l}\text { Tanya } \\
\text { jawab dan }\end{array}$ & $\begin{array}{l}\text { Pemateri } \\
\text { dan } \\
\text { peserta }\end{array}$ \\
\hline 3. & $\begin{array}{l}\text { Praktik } \\
\text { menulis } \\
\text { fiksi. }\end{array}$ & $\begin{array}{l}\text { Penugasa } \\
\text { nemberikan } \\
\text { masukan dan } \\
\text { saran atas } \\
\text { cerita yang } \\
\text { ditulis oleh } \\
\text { siswa. }\end{array}$ & Peserta \\
\hline 4. & Ceramah & $\begin{array}{l}\text { Pemateri } \\
\text { dan } \\
\text { peserta }\end{array}$ \\
\hline
\end{tabular}

\section{HASIL DAN PEMBAHASAN}

Pelaksanaan pengabdian kepada masyarakat dilaksanakan selama 1 hari dengan memberikan pelatihan menulis fiksi yang meliputi materi tentang mengenali tema cerita dan strategi menulis fiksi. Hasil yang dicapai dalam kegiatan pengabdian ini adalah meningkatnya ketertarikan para siswa dalam menulis fiksi. Hal ini dapat terlihat dari sikap antusias yang ditunjukkan para siswa dalam menyimak materi yang diberikan. Selain itu, para siswa juga banyak mengajukan pertanyaan seputar menulis fiksi. Proses diskusi seputar menulis fiksi berjalan dengan lancar dan menyenangkan. Para siswa mampu menghasilkan tulisan fiksi dalam waktu yang telah disepakati. Setelah praktik menulis fiksi, ditutup dengan memberi masukan atas tulisan para siswa.
Dengan kegiatan pengabdian kepada masyarakat ini, para siswa mendapatkan pengalaman tentang menulis karya fiksi. Kegiatan pengabdian kepada masyarakat ini dapat menjadi langkah awal bagi para siswa untuk menggali dan mengembangkan kemampuan/potensi diri dalam bidang menulis fiksi. Selain itu, dengan adanya kegiatan ini diharapkan para siswa akan termotivasi untuk menulis fiksi. Menulis fiksi dapat menjadi proses belajar bagi para siswa dalam meningkatkan keterampilan menulis.

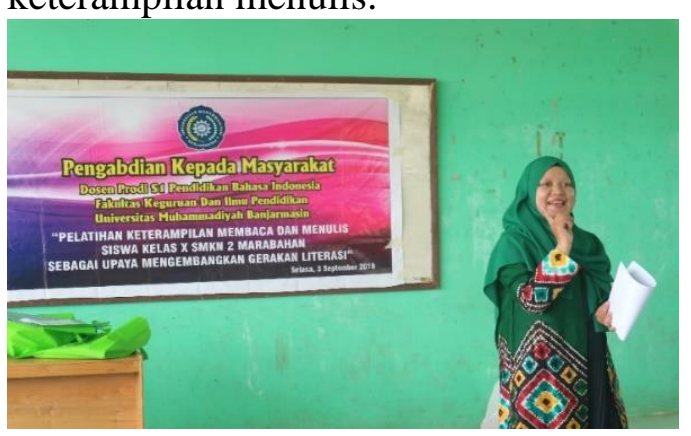

Gambar 1. Foto Pemateri menjelaskan tentang tema dan strategi menulis fiksi

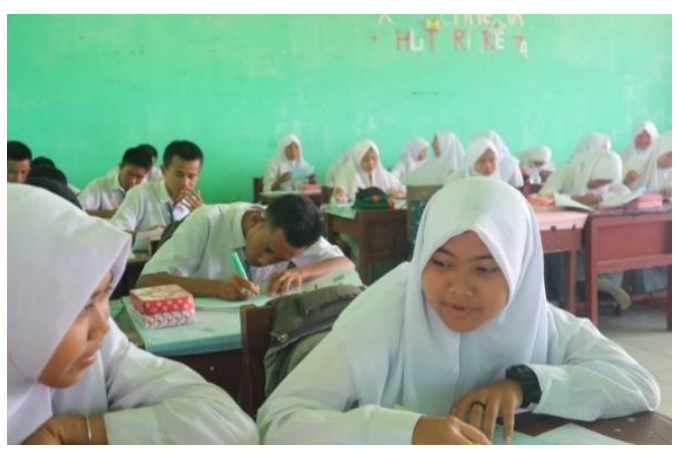

Gambar 2. Foto para siswa sedang praktik menulis fiksi

\section{SIMPULAN}

Berdasarkan kegiatan yang telah dilaksanakan, dapat disimpulkan bahwa menulis fiksi masih menjadi sesuatu yang tidak biasa bagi para siswa. Namun sudah ada ketertarikan untuk menulis fiksi setelah diberikan pelatihan menulis fiksi. para siswa menjadi memahami mekanisme menulis fiksi dan ada keinginan untuk menghasilkan sebuah 
cerita. Kultur budaya yang masih lekat dengan kehidupan siswa menjadi salah satu pendukung untuk menghasilkan sebuah fiksi yang bagus. Dewan guru diharapkan selalu memotivasi para siswa untuk tetap berlatih dan konsisten untuk menulis. Sebab dengan menulis, banyak manfaat yang akan didapatkan oleh para siswa.

\section{DAFTAR PUSTAKA}

[1] Dalman, Keterampilan Menulis. Jakarta: PT RajaGrafindo Persada, 2014.

[2] Nurhadi, Handboof of Writing. Jakarta: Bumi Aksara, 2017.

[3] Yunus, M, dkk, Keterampilan Menulis. Tangerang Selatan: Universitas Terbuka, 2014.

[4] Nurgiyantoro, Burhan, Teori Pengkajian Fiksi. Yogyakarta: Gadjah Mada University Press, 2015.

[5] Nugroho, Ipnu Rinto, Menjadi Penulis Kreatif. Yogyakarta: Notebook, 2014. 